\title{
Trichomoniasis in a Closed Community: Efficacy of Metronidazole
}

\author{
ELIZABETH E. KEIGHLEY
}

British Medical fournal, 1971, 1, 207-209

\section{Summary}

A retrospective survey of women treated in prison for trichomonal vaginitis with metronidazole showed that 488 of $496(98.3 \%)$ were cured after one course of drugs. Five of the eight treatment failures were successfully treated by further courses of metronidazole.

A regimen of $400 \mathrm{mg}$ metronidazole twice daily for seven days is simple and effective when taken in prescribed dosage. Metronidazole is still the drug of choice for trichomonal vaginitis. No toxic reactions were observed and there was no evidence that the drug has lost efficacy in the last ten years.

\section{Introduction}

The claims that hail the advent of new drugs have sometimes testified to the enthusiasm of the promoters rather than to the actual merits of their products and may have justified the cynical advice to use a new medicine before it has lost its efficacy. Even when the initial appraisal of an active chemical compound has proved to be correct it often has had to be modified later because of the development of drug resistance or the arrival of a newer and even more effective remedy. It was natural, therefore, that many expected that sooner or later metronidazole would be eclipsed or would cease to give such high rates of cure.

The publication abroad of papers representing that metronidazole (Flagyl) had begun to fail and rumours nearer home suggested the desirability of investigations designed to compare current cure rates in trichomoniasis with those obtained in the early 1960s. Accordingly a retrospective study was made of cases treated in the closed community of Holloway Prison, and this paper embodies the findings.

In order to compare the "response rate" of patients treated with metronidazole for trichomonal vaginitis in more recent years with that of previous years (Keighley, 1962), the case papers of all women treated by me in 1967 and 1968 at H.M. Prison, Holloway, were examined and the relevant data extracted.

As in prison it is customary to issue medicines only twice a day, this practice has been followed by my clinic in the giving of metronidazole ever since 1961. The patients on treatment were brought to the clinic twice daily for seven days; $400 \mathrm{mg}$ of metronidazole was given with a glass of water to the patient by the clinic sister, who watched the patient swallow her tablets. In this way it has always been checked that the patient received the correct dosage of the drug. This method of ensuring that the patient had her complete dose of metronidazole was not stressed in my paper in 1962; however, in retrospect, it appears to be the important factor in evaluating the efficacy of metronidazole.

When comparing results of treatment of inpatients at

Royal Northern Hospital, London N.7

ELIZABETH E. KEIGHLEY, L.R.C.P., L.R.C.S.ED., Honorary Consultant Venereologist (Lately Consultant to H.M. Prison, Holloway)
Holloway with those of outpatients at the Royal Northern Hospital, London, it became clear that the only difference was that the outpatients, particularly the young ones, were getting more careless every year about taking their tablets correctly. It was made as easy as possible-they were on the same twice-daily dosage as those in Holloway. But the outpatient who has forgotten to take her tablets or who has spread a week's tablets over two weeks is only too well known to us all.

The dosage in 1961-2 was $300 \mathrm{mg}$ - that is $1 \frac{1}{2}$ tablets-twice a day for seven days. Later many of the patients refused medication because of the bitter taste of the broken tablet. For this reason only, the dosage was standardized at $\mathbf{4 0 0} \mathbf{m g}$ (two 200-mg tablets) twice daily for seven days. No local treatment for trichomoniasis was given.

Criteria.-All patients fulfilling the following criteria were included in the present survey. (1) Those suffering from trichomonal vaginitis confirmed by wet-film microscopy and/or cytology. (2) Those treated with metronidazole $400 \mathrm{mg}$ twice daily for seven days. (3) Those followed up with tests of cure for a minimum period of two weeks. Patients with less than a two-week follow-up period have been reported, but are not included in the cure rate analysis.

\section{Retrospective Survey}

During 1967 and 19681,110 patients with trichomonal vaginitis were treated with metronidazole-549 in 1967 and 561 in 1968. Of these, 583 fulfilled the conditions for inclusion in the survey-293 from 1967 and 290 from 1968. Their ages ranged from 15 to 50 years (Table I). The age incidence of trichomoniasis in the women in prison usually

\begin{tabular}{|c|c|c|c|c|c|c|c|c|}
\hline & & & & $15-20$ & $21-30$ & $31-40$ & $41-50$ & $>50$ \\
\hline $\begin{array}{l}1967 \\
1968\end{array}$ & $\therefore$ & $\therefore$ & $\therefore$ & $\begin{array}{r}72 \\
103\end{array}$ & $\begin{array}{l}134 \\
126\end{array}$ & $\begin{array}{l}41 \\
35\end{array}$ & $\begin{array}{l}42 \\
21\end{array}$ & $\begin{array}{l}4 \\
5\end{array}$ \\
\hline Total & $\ldots$ & $\ldots$ & $\ldots$ & 175 & 260 & 76 & 63 & 9 \\
\hline
\end{tabular}

follows the pattern of the age incidence found in outpatient clinics, being highest in those aged 15-30 years, the years of highest sexual activity.

The 1967 figures shown in Table I give the usual picture; the sharp rise in those aged $15-20$ in 1968 was due to the opening of a new remand centre for the under-twenties in September 1967. The teenagers from various parts of England were concentrated in this one remand centre, inflating our figures and distorting the normal picture.

Of the 583 cases documented, $241(41 \cdot 3 \%)$ were prostitutes, either married or single, and $99(17 \%)$ were promiscuous. One girl aged 18 was virgo intacta. Marital status and details of sexual activity are shown in Table II. The higher the sexual activity the higher the incidence of Trichomonas vaginalis infestation, and therefore it is to be expected that those women engaged in prostitution will have a high rate of infestation. In fact it was found that the incidence of trichomoniasis in prostitutes was $54 \%$ in both 1967 and 1968 
TABLE II-Marital Status and Details of Sexual Activity

\begin{tabular}{|c|c|c|c|c|c|c|c|c|c|c|c|c|c|}
\hline & \multirow[b]{2}{*}{ Year } & & \multirow[b]{2}{*}{$\begin{array}{c}\text { Virgo } \\
\text { Intacta }\end{array}$} & \multicolumn{3}{|c|}{ Single } & \multicolumn{2}{|c|}{ Married } & \multirow[b]{2}{*}{$\begin{array}{c}\text { Divorced, } \\
\text { Separated } \\
\text { with Various } \\
\text { Partners }\end{array}$} & \multirow[b]{2}{*}{ Widows } & \multirow[b]{2}{*}{ Lesbians } & \multirow[b]{2}{*}{ Prostitutes } & \multirow[b]{2}{*}{ Totals } \\
\hline & & & & $\begin{array}{l}\text { Regular } \\
\text { Partner }\end{array}$ & $\begin{array}{l}\text { Various } \\
\text { Partners }\end{array}$ & Promiscuous & $\begin{array}{c}\text { Marital } \\
\text { Partner Only }\end{array}$ & $\begin{array}{c}\text { Extramarital } \\
\text { Consorts }\end{array}$ & & & & & \\
\hline $\begin{array}{l}1967 \\
1968\end{array}$ & 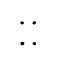 & . & $\begin{array}{l}1 \\
0\end{array}$ & $\begin{array}{r}10 \\
8\end{array}$ & $\begin{array}{l}33 \\
45\end{array}$ & $\begin{array}{l}46 \\
53\end{array}$ & $\begin{array}{l}47 \\
31\end{array}$ & $\begin{array}{l}11 \\
12\end{array}$ & $\begin{array}{l}22 \\
16\end{array}$ & $\begin{array}{l}5 \\
0\end{array}$ & $\begin{array}{l}2 \\
0\end{array}$ & $\begin{array}{l}116 \\
125\end{array}$ & $\begin{array}{l}293 \\
290\end{array}$ \\
\hline $\begin{array}{l}\text { Total } \\
\%\end{array}$ & 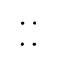 & . & $\begin{array}{l}1 \\
0 \cdot 2\end{array}$ & $\begin{array}{l}18 \\
3 \cdot 1\end{array}$ & $\begin{array}{l}78 \\
13 \cdot 4\end{array}$ & $\begin{array}{l}99 \\
17 \cdot 0\end{array}$ & $\begin{array}{l}78 \\
13 \cdot 4\end{array}$ & $\begin{array}{c}23 \\
3.9\end{array}$ & $\begin{array}{l}38 \\
6.5\end{array}$ & $\begin{array}{l}5 \\
0 \cdot 9\end{array}$ & $\begin{array}{l}2 \\
0 \cdot 3\end{array}$ & $\begin{array}{r}241 \\
41 \cdot 3\end{array}$ & $\begin{array}{l}583 \\
100\end{array}$ \\
\hline
\end{tabular}

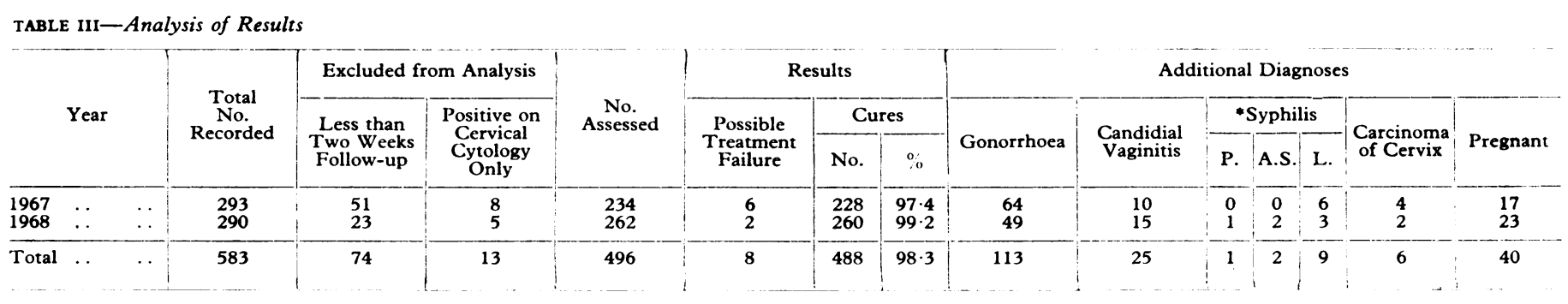

*Syphilis : P. = Primary. A.S. = Acute secondary. L. = Latent.

TABLE IV-Length of Observation in 488 Cases Treated Successfully

\begin{tabular}{|c|c|c|c|c|c|c|c|c|}
\hline & \multirow{3}{*}{$\begin{array}{l}\text { Total No. } \\
\text { Treated } \\
\text { Success- } \\
\text { fully }\end{array}$} & \multicolumn{7}{|c|}{ Post-treatment Follow-up } \\
\hline & & \multicolumn{3}{|c|}{ Weeks } & \multicolumn{4}{|c|}{ Months } \\
\hline & & 2 & 3 & 4 & -2 & -3 & -6 & -12 \\
\hline $\begin{array}{l}1967 \\
1968 \\
\end{array}$ & $\begin{array}{l}228 \\
260\end{array}$ & $\begin{array}{l}48 \\
56\end{array}$ & $\begin{array}{l}40 \\
50\end{array}$ & $\begin{array}{l}32 \\
58\end{array}$ & $\begin{array}{l}59 \\
60\end{array}$ & $\begin{array}{r}15 \\
7\end{array}$ & $\begin{array}{l}20 \\
21\end{array}$ & $\begin{array}{r}14 \\
8\end{array}$ \\
\hline Total & 488 & $\begin{array}{l}104 \\
100 \cdot 0\end{array}$ & $\begin{array}{l}90 \\
78 \cdot 7\end{array}$ & $\begin{array}{l}90 \\
60 \cdot 2\end{array}$ & $\begin{array}{r}119 \\
41 \cdot 8\end{array}$ & $\begin{array}{l}22 \\
17 \cdot 4\end{array}$ & $\begin{array}{l}41 \\
12.9\end{array}$ & $\begin{array}{r}22 \\
4 \cdot 5\end{array}$ \\
\hline
\end{tabular}

*These figures include patients followed-up at stated intervals and at all subsequent intervals.

(Keighley, 1969). Promiscuity, mainly in those aged 15-20, also results in a high incidence of trichomonal infestation. In 1968, of 791 girls aged $15-20$ years, $23 \%$ were found to have T. vaginalis.

\section{CLASSIFICATION OF CASES}

Patients were classified as follows:

Excluded from Analysis.-(1) Those who had less than two weeks' post-treatment follow-up $=$ incomplete test of cure. (2) Those who were negative for $T$. vaginalis on pretreatment direct smear but positive on cervical cytology; where no further cytology was undertaken the test of cure is taken as incomplete.

Included in Analysis.-(1) Possible treatment failures: those who failed to respond to the initial course or repeated courses of metronidazole. (2) Cures: those who responded to the initial course of metronidazole having had two weeks or more follow-up and no recurrence of the infestation.

\section{Results}

\section{EXCLUDED FROM ANALYSIS}

Of the 583 cases documented 87 were excluded from the "cure rate" analysis.

(1) Seventy-four patients $(12.7 \%)$ had less than two weeks' follow-up (2-10 days) (Table III). All were negative for $T$. vaginalis on direct film at posttreatment examination. Of these, 62 showed immediate clinical response; inflammation and irritation had subsided and there was no discharge. In the other 12 patients some discharge persisted; most of these had concurrent infections or cervical erosion. These 74 patients were women on remand in custody, before reappearing at court, who did not return to the prison.

(2) Thirteen patients were negative for $T$. vaginalis on pre- treatment direct film examination but were found to be positive on cervical cytology. After treatment with metronidazole smears were negative, but as no further cytology was undertaken the test of cure is taken as incomplete.

\section{INCLUDED IN ANALYSIS}

Response to Treatment.-Of the 496 cases taken into the cure rate assessment, $488(98.3 \%)$ were classified as "cures"; these were negative for $T$. vaginalis on direct film examination after one course of metronidazole and remained negative throughout the observation period. The length of observation in this group is shown in Table IV.

Treatment Failures.-Eight patients were classed as "treatment failures" and re-treated with the same dosage of metronidazole. Of these, six received a second course (four responded to treatment, one left the prison, and one refused further treatment) and two required a third course (one was negative on direct film examination throughout but positive on cervical cytology on two occasions (first and fifth weeks) and became negative on cytology after a third course of metronidazole; the other was re-treated twice but left the prison before follow-up examination was carried out). Details and summary of the pathological results in these eight cases are given in Table V.

\section{CLINICAL RESPONSE IN ALL CASES IN SURVEY}

Before treatment $95 \%$ of patients complained of a discharge and irritation; $30(5 \%)$ had no complaints and were symptom-free. After treatment with metronidazole, inflammation and irritation subsided and discharge cleared within four weeks in 418 patients $(71.7 \%)$. In 61 a scanty discharge remained which cleared at varying periods up to 12 weeks. In $74(12.7 \%)$ some discharge persisted, mostly due to other complicating conditions (Table VI). Time of examination after the start of treatment, when the patient was free of vaginal discharge, is shown in Table VI.

\section{ADVERSE REACTIONS}

There were no complaints of intolerance. I consider this to be due to the regular life of eating and sleeping and to the fact that the patient always received her tablets after a meal. 
TABLE V-Pathological Results in Eight Patients Needing Re-treatment

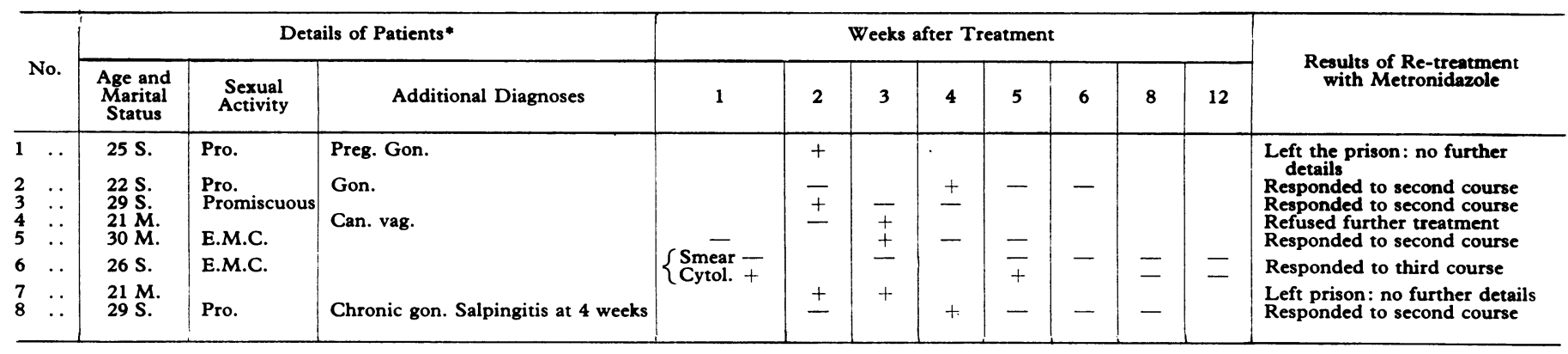

*S. $=$ Single. M. $=$ Married. Pro. $=$ Prostitute. E.M.C. $=$ Extramarital consorts. Preg. $=$ Pregnant. Gon. $=$ Gonorrhoea. Can. vag. $=$ Candidial vaginitis

TABLE VI-Clinical Response to Treatment

\begin{tabular}{|c|c|c|c|c|c|c|c|c|c|c|c|c|c|c|c|c|c|}
\hline & & & \multirow{3}{*}{$\begin{array}{c}\text { Symptom-free } \\
\text { Before } \\
\text { Treatment }\end{array}$} & \multirow{2}{*}{\multicolumn{5}{|c|}{$\begin{array}{l}\text { Time of Examination when } \\
\text { Free from Vaginal Discharge }\end{array}$}} & \multicolumn{8}{|c|}{ Persisting Discharge (74 patients) } & \multirow{3}{*}{ Tota } \\
\hline & & & & & & & & & \multicolumn{7}{|c|}{ Additional Diagnoses* } & \multirow{2}{*}{$\begin{array}{l}\text { T.V. } \\
\text { Only }\end{array}$} & \\
\hline & & & & $\begin{array}{l}7-10 \\
\text { days }\end{array}$ & $\begin{array}{c}2 \\
\text { weeks }\end{array}$ & $\begin{array}{c}-4 \\
\text { weeks }\end{array}$ & $\begin{array}{c}-8 \\
\text { weeks }\end{array}$ & $\begin{array}{c}-12 \\
\text { weeks }\end{array}$ & Gon. & $\begin{array}{l}\text { Can. } \\
\text { Vag. }\end{array}$ & $\begin{array}{l}\text { Cer. } \\
\text { eros. }\end{array}$ & C.P.S. & $\begin{array}{c}\mathrm{Ca} \\
\text { cerv. }\end{array}$ & Salp. & $\begin{array}{l}\text { Late } \\
\text { preg. }\end{array}$ & & \\
\hline \multirow{2}{*}{$\begin{array}{l}\text { No. } \\
\% \\
\%\end{array}$} & & \multirow{2}{*}{$\because$} & \multirow{2}{*}{$\begin{array}{l}30 \\
5 \cdot 2\end{array}$} & \multirow{2}{*}{$\begin{array}{r}\mathbf{8 4} \\
14 \cdot 4\end{array}$} & $\begin{array}{r}173 \\
29 \cdot 7 \\
\end{array}$ & \multirow[t]{2}{*}{$\begin{array}{c}161 \\
27 \cdot 6\end{array}$} & \multirow{2}{*}{$\begin{array}{c}49 \\
8 \cdot 4\end{array}$} & \multirow{2}{*}{$\begin{array}{c}12 \\
2 \cdot 0\end{array}$} & 16 & 10 & 15 & 1 & 1 & 1 & 6 & 24 & 583 \\
\hline & & & & & $71 \cdot 7$ & & & & \multicolumn{8}{|c|}{$12 \cdot 7$} & \\
\hline
\end{tabular}

*Additional diagnoses: Gon. = Gonorrhoea. Can. vag. = Candidial vaginitis. Cer. eros. = Cervical erosion. C.P.S. = Chronic pelvic sepsis. Ca. cerv. = Carcinoma of cervix. Salp. $=$ Salpingitis. Late preg. $=$ Late pregnancy.

Antibiotics were never given concurrently with metronidazole; if a specific infection was present it was treated before the trichomonal vaginitis.

\section{ADDITIONAL DIAGNOSES}

In 113 patients gonorrhoea as well as trichomonal vaginitis was present. Twenty-five had a concurrent candidial vaginitis for which they were given nystatin pessaries. Six patients were suffering from all three infections-that is, trichomonal gonorrhoeal, and candidial. Eight patients were treated topically with podophyllin for vaginal warts.

\section{Conclusions}

Finally, it is a good thing to pause and contemplate the change that oral medication for trichomonal vaginitis has made in women's lives. 'Flagyl' is now taken as a matter of course, and a whole generation has no knowledge of the suf- ferings of women with trichomoniasis before its introductionthe indignities and discomfort of the perpetual local treatment, douches, paintings, insufflations, and insertions of pessaries, etc. All these. things women suffered for months and sometimes years on end, only to relapse when the treatment was discontinued.

The results of this survey leave no doubt in my mind that metronidazole has not lost its efficacy and is still the drug of choice.

I gratefully acknowledge the co-operation of Dr. P. G. W. Pickering, Director of Prison Medical Services, for his permission to consult the records in H.M. Prison, Holloway, and of Dr. R. J. K. Blyth, senior medical officer, H.M. Prison, Holloway, who made the arrangements for me to do so.

\section{References}

Keighley, E. E. (1962). British Medical fournal, 2, 93.

Keighley, E. E. (1969). Annual Report of the Venereal Diseases Department, H.M. Prison, Holloway. 